\title{
Malignant Thoracic Neoplasm
}

National Cancer Institute

\section{Source}

National Cancer Institute. Malignant Thoracic Neoplasm. NCI Thesaurus. Code C3576.

A primary or metastatic malignant neoplasm affecting the tissues of the thorax. 